\title{
Changes in Congenital Anomaly Incidence in West Coast and Pacific States (USA) after Arrival of Fukushima Fallout
}

\author{
Joseph Mangano*, Janette D. Sherman \\ Radiation and Public Health Project, New York, USA \\ Email: ${ }^{*}$ odiejoe@aol.com
}

Received 24 February 2015; accepted 18 March 2015; published 19 March 2015

Copyright (C) 2015 by authors and Scientific Research Publishing Inc.

This work is licensed under the Creative Commons Attribution International License (CC BY).

http://creativecommons.org/licenses/by/4.0/

(c) (i) Open Access

\section{Abstract}

Radioactive fallout after the March 2011 Fukushima nuclear meltdown entered the U.S. environment within days; levels of radioactivity were particularly elevated in the five western states bordering on the Pacific Ocean. The particular sensitivity of the fetus to radiation exposure, and the ability of radioisotopes to attach to cells, tissues, and DNA raise the question of whether fetuses/newborns with birth defects with the greater exposures suffered elevated harm during the period after the meltdown. We compare rates of five congenital anomalies for 2010 and 2011 births from April-November. The increase of $13.00 \%$ in the five western states is significantly greater than the $3.77 \%$ decrease for all other U.S. states combined (CI $0.030-0.205, p<0.008$ ). Consistent patterns of elevated increases are observed in the west 20 of 21 comparisons, 6 of which are statistically significant/borderline significant), by state, type of birth defect, month of birth, and month of conception. While these five anomalies are relatively uncommon (about 7500 cases per year in the U.S.), sometimes making statistical significance difficult to achieve, the consistency of the results lend strength to the analysis, and suggest fetal harm from Fukushima may have occurred in western U.S. states.

\section{Keywords}

Birth Defects, Fukushima, Radiation, Meltdown, Nuclear Plant

\section{Introduction}

The harmful effects of radiation exposure to chromosomes have been known for nearly a century, starting with the discovery of chromosomal deformities in irradiated fruit flies [1]. Experiments with mice [2] [3] and rats [4] confirmed this knowledge, and documented elevated risk for congenital defects, at relatively low doses of ex-

${ }^{*}$ Corresponding author. 
posure. Populations exposed to pre-conception X-rays have been shown to have higher congenital anomalies [5] as were those living in areas with relatively high background radiation [6][7].

One form of radiation, byproducts of uranium or plutonium fission, was first introduced into the environment from weapons and reactors seven decades ago [8]-[10]. These isotopes bind with cells, tissues, and DNA of the unborn, and thus risks of congenital defects in irradiated populations have been studied. The first documented excesses of congenital anomalies were among children of survivors of the Hiroshima and Nagasaki bombings. [8]-[10]. During the 1950s, reports of various defects among newborns in the Marshall Islands, the site of 67 large-scale U.S. nuclear weapons tests, were made public. Other studies found links with between atmospheric tests and elevated birth defects, including a high rate of Down Syndrome in northwest England in 1963-1964, the peak period of global fallout from tests [11]. Another report documented elevated birth defect incidence near the Hanford nuclear weapons plant in Washington state (USA) [12].

The 1986 meltdown at Chernobyl produced numerous reports of certain congenital anomalies among populations subject to fallout from the stricken reactor. One documented a doubling of congenital developmental anomalies among infants born to fathers who worked as liquidators to contain the meltdown [13]. Various analyses presented elevated congenital anomaly rates in various parts of the Belarus region, which received the greatest doses of radioactivity from the meltdown, in the years following Chernobyl [14]-[22]. Other research also found high birth defect rates in the Ukraine [23] [24], Bulgaria [25], Croatia [26], and Germany [27]-[30] including areas with fallout levels well below those Belarussian sites closest to the reactor.

Post-Chernobyl studies also identified elevated rates of specific anomalies, the most-analyzed of which was Down syndrome (Trisomy-21), mostly in Germany [31]-[39]. Other conditions included neural tube defects in Turkey [40]-[43], cleft lip/palate in Germany [44] [45], and anencephaly in Turkey [46]. Meta-analyses concluded that a pattern of elevated congenital anomaly rates was associated with exposure to the Chernobyl meltdown [47]-[49].

No published reports exist on the change in congenital defects rates in Japan after the March 2011 meltdown at Fukushima. However, at least one report examines morphological abnormality rates in aphids in the first sexual reproduction period after the meltdown, and found a $13.2 \%$ rate close to Fukushima vs. $3.8 \%$ in seven control areas [50].

Changes in the rate of one type of birth defect, congenital hypothyroidism, have been reported. In the five U.S. states bordering on the Pacific Ocean, with the most elevated levels of environmental radiation after the meltdown, a 16\% increase in incidence of the disorder was observed in the nine months following the meltdown, compared to a $3 \%$ decrease in 36 other U.S. states [51]. The gap was particularly large (28\% increase vs. a $4 \%$ decrease) in the first 14 weeks after the arrival of fallout. In addition, the rate of California newborns with a Thyroid Stimulating Hormone score of 19 micro international units per milliliter of blood during initial screening, was $27 \%$ greater in the nine months after the meltdown compared to other periods in 2011-2012 [52]. The known affinity for radioactive iodine to attack cell membranes and DNA in the thyroid gland indicates a potential link between Fukushima fallout and congenital hypothyroidism.

Historical reports linking exposure to ionizing radiation with congenital anomaly risk, plus the initial reports on congenital hypothyroidism in the western U.S. suggest further analysis be conducted on other birth defects.

The U.S. Centers for Disease Control and Prevention (CDC) publishes national data collected by state health departments on incidence of five congenital anomalies in the nation. These include Anencephaly, Cleft Lip/Palate, Down Syndrome, Omphalocele/Gastroschisis, and Spina Bifida/Meningocele [53]. Approximately 7500 cases of these five defects occur in the U.S. each year. As of mid-2014, the CDC web site contained complete birth defect data for the years 2007 to 2012.

These five specific anomalies to be addressed in this report, merit some discussion, including their suspected link with radiation exposure.

Anencephaly is a type of neural tube defect in which the baby is missing major portions of the brain and skull, resulting in stillbirths or death within the perinatal period. Neural tube defects, which begin during the first month of pregnancy, have been reduced by increased intake of folic acid during pregnancy. Conversely, risk of anencephaly has been found to increase due to exposure to X-rays and neutrons in mouse zygotes [54].

Cleft palate or cleft lip are marked by a (usually unilateral) separation of the upper lip and palate, due to faulty fusion of the medial, nasal, and maxillary processes. The condition can be surgically repaired in some cases, but requires special care of the infant to prevent choking or aspiration until the surgery can be performed. Among the risk factors identified for cleft palate/lip are environmental pollutants, including radiation exposure [55]. 
Down syndrome, also Trisomy-21, features growth delays, similar facial and hand features and substantial intellectual deficits. The majority of cases detected during pregnancy in the developed world result in abortion. Known causes are still emerging, but exposure to radiation and other chemical toxins have been established as one. Down syndrome is the most-studied congenital defect after the Chernobyl meltdown.

Gastroschisis occurs when the muscles of the abdomen do not close along the mid-ventral line and the intestines and liver remain outside the abdomen. Omphalocele, a related condition in which the intestines and liver remain outside the body at birth, is a defect much larger than gastroschisis. It occurs when the viscera occupy a thin sac of peritoneum located at the base of the umbilical cord. Gastroschisis risk has been found to be elevated after maternal irradiation, even at relatively low doses [56].

Spina Bifida/meningocele is a prenatal failure of the embryonic neural tube to close over the spinal cord, leaving the cord unprotected by the bony cover and open to trauma and infection. When only the membrane covering the spinal cord encloses the protruding fluid-filled sac, the condition is known as menigocele. Surgical repair is sometimes successful, but many with the disorder suffer mental, neurological, and other physical disabilities. Radiation exposure has been linked with risk of this disorder [57].

Our hypothesis is that the 2010-2011 rate change of these five anomalies increased more sharply in the five Pacific/West Coast states than the rest of the U.S., based on the presence of elevated levels of fallout from the Fukushima meltdown in the period following March 2011, and the well-documented pattern of risk to humans irradiated in utero.

\section{Materials and Methods}

One important component of the methodology identifies areas of the U.S. with the greatest exposure levels after Fukushima fallout entered the environment. Unfortunately, official measurements of isotope-specific concentrations are very limited. For example, the U.S. Environmental Protection Agency (EPA) measured just 77 samples of Iodine-131 in precipitation in the U.S. during spring 2011, of which 70 revealed a detectable amount-with no such samples in the same period of 2010_far short of a reliable sample. The number of other isotope-specific samples is well below 77 for 2011, and virtually zero in 2010 [58].

The only measure of radioactivity with large numbers of measurements in the period just after Fukushima, when environmental radiation was highest (March 15-April 30, 2011), along with the prior year, is not a specific isotope, but airborne beta emitters, or "gross beta". During this 47 day period, well over 1000 samples with detectable concentrations were collected by the EPA at over 100 U.S. stations. Because gross beta is a broad measure, it is reasonable to use it as a proxy for relative exposures in this report. The most elevated levels of environmental radioactivity in the U.S. after Fukushima occurred in the states bordering the Pacific Ocean (California, Oregon, and Washington), plus Alaska and Hawaii. Table 1 shows the increase in airborne gross beta radioactivity for 18 sites in the five states, compared to 31 other U.S. sites with the most frequently reported data (typically 1 - 2 measurements per week). We also present the increase for 10 of the 18 sites in the five states that consistently report data (1 - 2 measurements per week), which show similar patterns.

In a previous report, we summarized EPA measurements on the 2010 and 2011 gross beta from January 1 to October 4 [51] — the most recent data at the time, and a reasonable measure of relative dose to the U.S. population in the two years in the period of highest Fukushima fallout and other periods.

For most of the period January 1 to October 4, the ratio of 2011 to 2010 beta averages was similar across the U.S. (0.983 for 18 sites in the western states, 1.018 for 31 non-western U.S. sites). But in the period March 15 to April 30, immediately after Fukushima fallout arrived, the 2011/2010 ratio for the 18 sites in the western states (7.345), was considerably higher than the 31 non-western U.S. sites (2.397). Although this is not a comprehensive assessment of dose by geographic area, it supports the belief that the greater exposures from the meltdown occurred in the five western states, using a broad measure of radiation such as gross beta. Appendix 1 shows the radiation measurement sites used.

The group that will be most susceptible to damage are those in utero during the period of highest environmental radioactivity levels (March 15 to April 30, 2011). March 2011 births were not included because those born early in the month were born before Fukushima. December 2011 births were not included, since 5\% were not conceived by April 30, and another 5\% were conceived in late April, when radiation levels were elevated, but well below those in late March.

This report will compare 2010 and 2011 rates of five birth defects for births during the eight months of April 
to November. The five Pacific/West Coast states will be compared with the other 45 states (plus the District of Columbia). Virtually all 2011 births in these months were in utero during the period of highest fallout in the spring of 2011, testing the hypothesis that elevated congenital anomaly rates occurred as fetuses were exposed to Fukushima radiation. The birth defect rates are given in cases per 100,000 births. Only those births in which a "yes" or "no" is given for presence of a birth defect in the CDC web site are included in the denominator; excluded are $0.80 \%$ of 2010 and 2011 births with the anomaly status "not stated".

Included in the analysis will be the total of all births in the eight-month period, along with subsets (by month of birth, state, type of birth defect, month of conception, and birth weight). Birth defect rates by month of conception will include live births conceived in September, October, November, and December 2010, meaning they were in their $3^{\text {rd }}, 4^{\text {th }}, 5^{\text {th }}$, and $6^{\text {th }}$ month in utero when the Fukushima meltdown occurred. These will be compared with cohorts conceived at the same time for the prior year (conceived September to December 2009). To obtain month of conception, the month of birth and weeks of gestation at birth were matched (Table 2). Only those births of at least 29 weeks gestation, including about $97 \%$ of live births, are included, since some of those April-November 2011 births with shorter gestation periods were born before the meltdown.

Table 1. Change in average airborne gross beta concentrations, five pacific/west coast states vs. other U.S., 2010-2011.

\begin{tabular}{|c|c|c|c|}
\hline \multicolumn{4}{|c|}{ Average Airborne Gross Beta Concentrations (n) } \\
\hline$\underline{\text { Year }}$ & 5 States (18 Sites) & 5 States (10 Sites) & Other U.S. \\
\hline \multicolumn{4}{|l|}{ March 15-April 30} \\
\hline 2010 & $0.005112(190)$ & 0.005130 (132) & $0.008527(401)$ \\
\hline 2011 & $0.033016(225)$ & 0.029563 (138) & $0.020204(378)$ \\
\hline 2011/2010 Ratio ${ }^{* *}$ & 7.345 & 5.253 & 2.397 \\
\hline \multicolumn{4}{|c|}{$\underline{\text { Other Dates January 1-October } 4}$} \\
\hline 2010 & 0.006027 (853) & $0.006184(660)$ & $0.009573(1810)$ \\
\hline 2011 & $0.005526(858)$ & $0.005550(564)$ & 0.009670 (1679) \\
\hline 2011/2010 Ratio ${ }^{* *}$ & 0.983 & 0.0889 & 1.018 \\
\hline 3/15-4/30 ratio/ & 7.472 & 5.909 & 2.355 \\
\hline Other Dates ratio & & & \\
\hline
\end{tabular}

${ }^{*}$ Ten sites in West Coast/Pacific states report gross beta regularly (at least 11 measurements for each site in spring 2010 and 2011 , and at least 44 measurements for other January 1-October 4 in 2010 and 2011); the column with 18 sites includes those with less regular measurements; ${ }^{* *}$ Ratios represent total gross beta averages for all sites divided by number of sites; Source: United States Environmental Protection Agency. Envirofacts. http://oaspub.enviro/erams.gov_query.simple_query. All averages in picocuries of gross beta per cubic meter of air.

Table 2. Computation of month of conception, by birth month and weeks gestation at birth.

\begin{tabular}{llcccccc}
\hline & \multicolumn{7}{c}{ Weeks Gestation at Birth } \\
\hline Conceived & & $\underline{29-32}$ & $\underline{33-36}$ & $\underline{37-40}$ & $\underline{41-44}$ & $\underline{45-47}$ \\
Sept. 2010 & Born & $4 / 11$ & $5 / 11$ & $6 / 11$ & $7 / 11$ & $8 / 11$ \\
Oct. 2010 & Born & $5 / 11$ & $6 / 11$ & $7 / 11$ & $8 / 11$ & $9 / 11$ \\
Nov. 2010 & Born & $6 / 11$ & $7 / 11$ & $8 / 11$ & $9 / 11$ & $10 / 11$ \\
Dec. 2010 & Born & $7 / 11$ & $8 / 11$ & $9 / 11$ & $10 / 11$ & $11 / 11$ \\
Sept. 2009 & Born & $4 / 10$ & $5 / 10$ & $6 / 10$ & $7 / 11$ & $8 / 10$ \\
Oct. 2009 & Born & $5 / 10$ & $6 / 10$ & $7 / 10$ & $8 / 11$ & $9 / 10$ \\
Nov. 2009 & Born & $6 / 10$ & $7 / 10$ & $8 / 10$ & $9 / 11$ & $10 / 10$ \\
Dec. 2009 & Born & $7 / 10$ & $8 / 10$ & $9 / 10$ & $10 / 11$ & $11 / 10$ \\
\hline
\end{tabular}

Source: U.S. Centers for Disease Control and Prevention (http://wonder.cdc.gov/natality.html). 
The statistical significance of differences in 2010-2011 changes between the two groups of states will be tested using a formula (below) that creates a 95\% confidence interval of the differences [59]. If the upper and lower bounds of the confidence interval both exceed zero, the difference is statistically significant.

VAR SIR $1=\left[\left(5\right.\right.$ State $\mathrm{SE}_{1}^{2} *$ Other US Rate $\left.{ }_{1}^{2}\right)+\left(\right.$ Other US $\mathrm{SE}_{1}^{2} * 5$ State Rate $\left.\left._{1}^{2}\right)\right) /$ Other US Rate $\left.{ }_{1}^{4}\right]$

VAR SIR $2=$ [(5 State $\mathrm{SE}_{2}^{2} *$ Other US Rate $\left.{ }_{2}^{2}\right)+\left(\right.$ Other US $\mathrm{SE}_{2}^{2} * 5$ State Rate $\left.\left._{2}^{2}\right)\right) /$ Other US Rate ${ }_{2}^{4}$ ]

SIR stands for Standard Incidence Ratio, SE for Standard Error, and Rate for Cases of a Defect per 100,000. The subscript of ${ }_{1}$ represents the year 2010, while the subscript of ${ }_{2}$ represents the year 2011. To convert a confidence interval to a p-value (any value under 0.05 is considered statistically significant), an exponential function using the z-score in the following formula (inverse of a logarithm) is used:

$\mathrm{p}=\exp \left((-0.717 *(\right.$ absolute value $\mathrm{z}))-\left(0.416 * \mathrm{z}^{2}\right)$

The $\mathrm{z}$ score is obtained by subtracting the lower limit from the upper limit of the confidence interval, and dividing the result by the Standard Error.

\section{Results}

The 2010-2011 change in incidence rates of all five birth defects combined, for births during the eight months of April to November, along with the two four-month periods, are given in Table 3.

The birth defect rate for all five defects combined increased $+13.00 \%$ in the five Pacific/West Coast states for births from April to November. During this time, the number of diagnosed cases rose from 600 to 672 . The corresponding rate for the rest of the U.S. decreased $-3.77 \%$, as the number of cases declined from 4378 to 4180 . This difference was statistically significant (CI $0.030-0.205$, p < 0.008). For births in the two four month periods, the rates increased for western states and declined for all other U.S. states $(+10.85 \%$ vs. $-3.38 \%$ for April-July births, and $+15.12 \%$ vs. $-1.26 \%$ for August-November births). Differences were statistically significant for the earlier four months (CI $0.004-0.246, \mathrm{p}<0.05$ ) and of borderline significance for the latter four months (CI -0.006 - 0.230, $\mathrm{p}<0.07$ ).

These 2010-2011 changes in all defects combined for April-November births are presented for each of the five states (residency of mother at birth) in Table 4.

A 2010-2011 increase in birth defect rates was observed for each of the five states, including Alaska (+69.52\%), California (+11.88\%), Hawaii (+3.90\%), Oregon (+8.87\%), and Washington $(+15.53 \%)$. Compared to the $-3.77 \%$ decline for all other U.S. states, only the California increase achieved statistical significance (CI

Table 3. Change in incidence rates, five birth defects combined, April/November 2010 vs. April/November 2011 births, five pacific/west coast states vs. other U.S.

\begin{tabular}{|c|c|c|c|}
\hline & $\underline{\text { Rate } / 100,000(n)}$ & $\underline{\text { Rate } / 100,000(n)}$ & $\underline{95 \% \mathrm{CI} /}$ \\
\hline Birth Date & $\underline{5 \text { States }}$ & Other U.S. & Significance \\
\hline \multicolumn{4}{|c|}{ April-November (8 months) } \\
\hline 2010 & $133.22(600)$ & $196.90(4378)$ & \\
\hline 2011 & $150.54(672)$ & $189.47(4180)$ & \\
\hline$\%$ Ch. Rate & $13.00 \%$ & $-3.77 \%$ & $0.030-0.205(\mathrm{p}<0.008)$ \\
\hline \multicolumn{4}{|c|}{ April-July (4 months) } \\
\hline 2010 & $134.61(297)$ & $197.93(2178)$ & \\
\hline 2011 & $149.22(331)$ & $190.36(2018)$ & \\
\hline \% Ch. Rate & $10.85 \%$ & $-3.38 \%$ & $0.004-0.246(\mathrm{p}<0.05)$ \\
\hline \multicolumn{4}{|c|}{ August-November (4 months) } \\
\hline 2010 & $131.90(303)$ & $195.89(2200)$ & \\
\hline 2011 & $151.84(341)$ & $193.43(2162)$ & \\
\hline$\%$ Ch. Rate & $15.12 \%$ & $-1.26 \%$ & $-0.006-0.230(\mathrm{p}<0.07)$ \\
\hline
\end{tabular}

Source: U.S. Centers for Disease Control and Prevention (http://wonder.cdc.gov/natality.html). 
Table 4. Change in incidence rates, five birth defects combined, April-November 2010 vs. April-November 2011 births, each of five pacific/west coast states vs. other U.S.

\begin{tabular}{|c|c|c|c|}
\hline & & & $95 \% \mathrm{CI} /$ \\
\hline$\underline{\text { State }}$ & $\underline{\text { Rate } / 100,000(n)}$ & \% Ch. Rate & Significance \\
\hline \multicolumn{4}{|l|}{$\underline{\text { Alaska }}$} \\
\hline 2010 & $152.30(10)$ & & \\
\hline 2011 & $258.18(15)$ & $69.52 \%$ & \\
\hline \multicolumn{4}{|c|}{$\underline{\text { California }}$} \\
\hline 2010 & $101.73(349)$ & & \\
\hline 2011 & $113.81(385)$ & $11.88 \%$ & $0.001-0.167(\mathrm{p}<0.05)$ \\
\hline \multicolumn{4}{|l|}{$\underline{\text { Hawaii }}$} \\
\hline 2010 & $250.39(32)$ & & \\
\hline 2011 & $260.15(33)$ & $3.90 \%$ & \\
\hline \multicolumn{4}{|l|}{ Oregon } \\
\hline 2010 & $304.15(94)$ & & \\
\hline 2011 & $331.13(102)$ & $8.87 \%$ & \\
\hline \multicolumn{4}{|c|}{ Washington } \\
\hline 2010 & 201.56 (115) & & \\
\hline 2011 & $232.86(137)$ & $15.53 \%$ & \\
\hline \multicolumn{4}{|c|}{ Other U.S. } \\
\hline 2010 & 196.90 (4378) & & \\
\hline 2011 & $189.47(4180)$ & $-3.77 \%$ & \\
\hline
\end{tabular}

Source: U.S. Centers for Disease Control and Prevention (http://wonder.cdc.gov/natality.html).

$0.001-0.167, \mathrm{p}<0.05$ ), as $58 \%$ of the birth defects in the five states occur to California residents. The unusually large rise in Alaska is countered by the small number of cases (10 and 15 for each year), rendering the change not statistically significant.

In addition to each state, changes for each type of birth defect are analyzed. Table 5 compares 2010-2011 incidence changes for the five West Coast/Pacific states combined with those of all other U.S. states, for AprilNovember births.

For each of the five defects, we observe an increase from 2010-2011 in the five West Coast/Pacific states and a decline in the remaining states. However, none of the differences were statistically significant. The largest difference in the change of the two areas occurred for Anencephaly ( $+41.24 \%$ vs. $-3.13 \%)$; however, this defect is the rarest of the five (in the Pacific/West Coast states, the 2010 total of 30 cases rose to 42 the following year), and thus is not significant. The difference in changes was also substantial for Omphalocele/Gastroschisis $(+23.86 \%$ vs. $-0.55 \%)$; the difference was the closest of the five to achieve statistical significance $(\mathrm{p}<0.17)$.

Changes in congenital anomaly incidence are also analyzed according to the number of weeks of gestation at birth. Table 6 provides this information, for births at 17 - 32 weeks, 33 - 36 weeks, 37 - 40 weeks, and 41 - 47 weeks.

Again, incidence in the West Coast/Pacific states increased, and declined for all other U.S. states, for each of the four gestation groups. The difference for those births within the normal gestation of 37 - 40 weeks $(+16.05 \%$ vs. $-3.52 \%$ ) was statistically significant (CI $0.015-0.257$, p $<0.03$ ), as $64 \%$ of the five birth defects occur in this group. Gaps in the differences in changes of the two groups of over 20 percentage points were observed for the lowest (17 - 32 weeks) and highest (41 - 47 weeks) gestation groups, although neither was statistically significant. 
Table 5. Change in incidence rates, each of five birth defects, April-November 2010 vs. April-November 2011 births, five pacific/west coast states vs. other U.S.

\begin{tabular}{|c|c|c|}
\hline & $\underline{\text { Rate } / 100,000(\mathrm{n})}$ & $\underline{\text { Rate } / 100,000(\mathrm{n})}$ \\
\hline Birth Defect & 5 States & Other U.S. \\
\hline \multicolumn{3}{|l|}{ Anencephaly } \\
\hline 2010 & $6.66(30)$ & $11.56(257)$ \\
\hline 2011 & $9.41(42)$ & $11.20(247)$ \\
\hline$\%$ Ch. Rate & $41.24 \%$ & $-3.13 \%$ \\
\hline \multicolumn{3}{|l|}{$\underline{\text { Cleft Lip/Palate }}$} \\
\hline 2010 & $56.84(256)$ & 76.05 (1691) \\
\hline 2011 & $59.59(266)$ & 72.03 (1589) \\
\hline \% Ch. Rate & $4.83 \%$ & $-5.29 \%$ \\
\hline \multicolumn{3}{|c|}{ Down Syndrome } \\
\hline 2010 & 38.63 (174) & 51.09 (1136) \\
\hline 2011 & 43.91 (196) & $50.00(1103)$ \\
\hline$\%$ Ch. Rate & $13.64 \%$ & $-2.14 \%$ \\
\hline \multicolumn{3}{|c|}{ Omphalocele/Gastroschisis } \\
\hline 2010 & $22.43(101)$ & 40.75 (906) \\
\hline 2011 & $27.78(124)$ & $40.52(894)$ \\
\hline \% Ch. Rate & $23.86 \%$ & $-0.55 \%$ \\
\hline \multicolumn{3}{|c|}{$\underline{\text { Spina Bifida/Meningocele }}$} \\
\hline 2010 & 8.86 (39) & $17.00(378)$ \\
\hline 2011 & $9.86(44)$ & $15.82(349)$ \\
\hline$\%$ Ch. Rate & $13.82 \%$ & $-6.94 \%$ \\
\hline
\end{tabular}

Source: U.S. Centers for Disease Control and Prevention (http://wonder.cdc.gov/natality.html).

We also address 2010-2011 changes in birth defect rates for the pre- and post-Fukushima birth cohorts by month of conception. In the methods section, the number of birth defects and live births for those conceived September, October, November, and December 2009 and 2010, with gestation periods 29 - 47 weeks, are identified. Table 7 compares the changes in rates for the four sets of birth cohorts.

For newborns conceived in October and December, the 2010-2011 change in the congenital anomaly rate was roughly equal for the West Coast/Pacific states and the remainder of the U.S. For those conceived in November, the rate change in the west $(+33.64 \%)$ was much higher than the other U.S. states $(-1.41 \%)$. Those conceived in November 2010 were four months in utero when the Fukushima meltdown occurred. The difference was of borderline significance ( $\mathrm{CI}-0.024-0.478, \mathrm{p}<0.08$ ). The difference for those conceived in September was substantial (+20.35\% vs. $-7.68 \%)$, but fell short of statistical significance.

\section{Discussion}

This report addresses changes in rates of certain birth defects after the Fukushima nuclear meltdown. While we await the critical data from Japan, where the greatest exposures occurred, we focus on the USA. Our hypothesis that areas in the U.S. which received elevated levels of environmental radioactivity from the Fukushima meltdown are at risk for increased birth defects is based on the documented evidence of cellular damage from radiation exposure, the particular sensitivity of the fetus to radiation, and numerous reports of elevated congenital 
Table 6. Change in incidence rate, five birth defects, April-November 2010 vs. April-November 2011 births, five pacific/west coast states vs. other U.S. by weeks gestation at birth.

\begin{tabular}{|c|c|c|c|}
\hline & & & 95\% Conf. Int./ \\
\hline & $\underline{\text { Rate } / 100,000(\mathrm{n})}$ & $\underline{\text { Rate } / 100,000(n)}$ & Significance \\
\hline$\underline{\text { Weeks }}$ & $\underline{5 \text { States }}$ & Other U.S. & \\
\hline \multicolumn{4}{|l|}{$\underline{17-32 \text { weeks }}$} \\
\hline 2010 & $441.66(38)$ & $502.32(296)$ & \\
\hline 2011 & $539.21(46)$ & $516.84(296)$ & \\
\hline \% Ch Rate & $22.09 \%$ & $2.89 \%$ & \\
\hline \multicolumn{4}{|l|}{$\underline{33-36 \text { weeks }}$} \\
\hline 2010 & $358.92(128)$ & $441.81(942)$ & \\
\hline 2011 & 376.06 (129) & 440.72 (909) & \\
\hline$\%$ Ch Rate & $4.78 \%$ & $-0.25 \%$ & \\
\hline \multicolumn{4}{|l|}{$\underline{37-40 \text { weeks }}$} \\
\hline 2010 & $110.57(377)$ & $165.31(2729)$ & \\
\hline 2011 & $128.32(435)$ & $159.48(2612)$ & \\
\hline \% Ch Rate & $16.05 \%$ & $-3.52 \%$ & $0.015-0.257(\mathrm{p}<0.03)$ \\
\hline \multicolumn{4}{|l|}{$\underline{41-47 \text { weeks }}$} \\
\hline 2010 & $87.50(57)$ & $136.78(411)$ & \\
\hline 2011 & $96.01(62)$ & $119.10(363)$ & \\
\hline$\%$ Ch Rate & $9.73 \%$ & $-12.93 \%$ & \\
\hline
\end{tabular}

Source: U.S. Centers for Disease Control and Prevention (http://wonder.cdc.gov/natality.html).

anomaly rates after exposure to fallout from atomic bomb detonations and nuclear reactor meltdowns.

We find a consistent pattern of excess 2010-2011 increases in birth defect rates in the five West Coast/Pacific states, compared to the rest of the U.S., for the eight-month period April-November. The April-November 2011 birth cohort was exposed to Fukushima radioactivity while in utero. Analyses are presented by birth month, state, defect, gestation length, and conception month. There was a greater increase in the five West Coast/Pacific states in 20 of 21 comparisons. There were four categories that achieved statistical significance at $\mathrm{p}<0.05$ or less, including all defects combined ( $\mathrm{p}<008)$, April-July births $(\mathrm{p}<0.05)$, California births $(\mathrm{p}<0.05)$, and births 37 - 40 weeks gestation ( $<<0.03$ ). Two others were borderline significant at $\mathrm{p}<0.10$, including AugustNovember births $(\mathrm{p}<0.07)$ and births conceived the prior November $(\mathrm{p}<0.08)$. Changes in categories with relatively small numbers of anomalies, such as individual months, are consistently elevated for the West Coast/ Pacific state but vary greatly, often fail to achieve significance, and demonstrate no consistent pattern.

The relatively small number of events in many of the 21 comparisons makes it difficult to achieve statistical significance. However, the consistency of results, namely that the increase in the five West Coast/Pacific states is greater in 20 of 21 comparisons, lends strength to the analysis.

This is just the first attempt to analyze post-2010 changes in U.S. congenital anomaly rates, and proposes a hypothesis that one potential factor-radioactive fallout from a nuclear reactor meltdown-might account for temporal increases in the most-affected areas. The results need to be augmented by consideration of the many other potential factors that might contribute to such trends. Just a few examples of these many factors include access to medical care, poverty status, preventative measures prior to birth, and exposure to other environmental toxins. We strongly encourage analyses of other factors.

These trends merit further analysis. The annual rate of cases per 100,000 live births (April to November) for the five West Coast/Pacific states moved from 150.71 (2009), to 133.22 (2010), to 150.04 (2011). Thus, the rise from 
Table 7. Change in incidence rates, five birth defects, April-November 2010 vs. April-November 2011 births, five pacific/west coast states vs. other U.S. by month conceived, Sept.-December 2010.

\begin{tabular}{|c|c|c|c|}
\hline & & & $95 \% \mathrm{CI} /$ \\
\hline \multicolumn{2}{|c|}{$\underline{\text { Rate } / 100,000(n)}$} & $\underline{\text { Rate } / 100,000(n)}$ & Significance \\
\hline Conceived & $\underline{5 \text { States }}$ & Other U.S. & \\
\hline \multicolumn{4}{|c|}{ December, prior to year below } \\
\hline 2010 & $143.99(84)$ & $186.58(525)$ & \\
\hline 2011 & $149.04(84)$ & $194.17(542)$ & \\
\hline$\%$ Ch Rate & $3.51 \%$ & $4.07 \%$ & \\
\hline \multicolumn{4}{|c|}{$\underline{\text { November, prior to year below }}$} \\
\hline 2010 & $119.61(70)$ & $187.22(534)$ & \\
\hline 2011 & $159.85(93)$ & $184.58(537)$ & \\
\hline$\%$ Ch Rate & $33.64 \%$ & $-1.41 \%$ & $-0.024-0.478(\mathrm{p}<0.08)$ \\
\hline \multicolumn{4}{|c|}{ October, prior to year below } \\
\hline 2010 & $142.05(81)$ & $198.30(558)$ & \\
\hline 2011 & $129.82(74)$ & $176.72(504)$ & \\
\hline \% Ch Rate & $-8.61 \%$ & $-10.88 \%$ & \\
\hline \multicolumn{4}{|c|}{$\underline{\text { September, prior to year below }}$} \\
\hline 2010 & $140.38(77)$ & $206.69(570)$ & \\
\hline 2011 & $168.89(94)$ & $190.82(526)$ & \\
\hline \% Ch Rate & $20.35 \%$ & $-7.68 \%$ & \\
\hline
\end{tabular}

Source: U.S. Centers for Disease Control and Prevention (http://wonder.cdc.gov/natality.html).

2010-2011, representing those births in utero at the time of Fukushima, was preceded by a decline from 20092010. Potential long-term changes after exposure to Fukushima fallout after 2011 should be addressed in future reports.

The five birth defects included in this analysis are relatively uncommon, accounting for about 7500 annual cases among 4,000,000 U.S. births, but are unmistakable in diagnosis. We note that rates of the five birth defects are lower in the West Coast/Pacific states than that in the U.S. as a whole. Identifying reasons that may account for this pattern — such as racial and ethnic distribution, poverty, access to health care, and medical risk factorsshould be made. However, it is unlikely that changes in these potential causes over a short time (2010 vs. 2011) would account for such large and consistent differences in temporal changes between areas with different levels of irradiation.

Since changes in birth defect rates after Fukushima is a yet-unaddressed topic, a number of additional analyses can be made, which we present here.

Defining pre- and post-Fukushima periods is one area of further analysis. We selected the years 2010 and 2011, as we believe that the best representation of a period prior to an event like a meltdown is that immediately before it occurs. However, future reviews might expand on these time periods. Data on birth defect rates beginning 2007 are available, so two- , three- , and four-year baselines can be used, and birth defect data after 2011 merit consideration as they become available.

We present 2010-2011 gross beta data comparisons not just after Fukushima when fallout was highest, but also in the relatively unexposed time frame of all but 47 days of the 277 days from January 1 to October 4 . In future analyses, contrasting these data for shorter periods, such as individual months, might be helpful to assess any changes from year to year.

Another major issue raised by studies such as this is defining relative doses or exposures to populations. We 
use airborne gross beta measurements as a proxy for relative exposure to Americans soon after Fukushima. While the number of gross beta measurements in the selected U.S. sites are large (591 and 603 in the period March 15 to April 30, in 2010 and 2011), we acknowledge the lack of other frequently-conducted radiation measures. In particular, specific isotope concentrations in air, water, soil, and food are virtually non-existent (which also occurred after the 1986 Chernobyl meltdown, with even larger fallout levels than post-Fukushima). It is critical that officials need to expand future sampling programs in order to enable greater ability in assessing dose-response relationships. Until that happens, however, we recognize that any health study, using the most meaningful data possible, is crucial to better understanding of this most important topic-even if a precise dose-response is still in its early phases. The much greater rise in airborne gross beta in the west coast and Pacific states (vs. the rest of the U.S.) from spring 2010 to spring 2011 is a clear indicator of relatively greater exposures occurring in this area from fallout after the Fukushima catastrophe. The linear no-threshold model has been accepted by many to be most consistently observed in studies [60], but further studies of effects of overall doses are needed to possibly further refine the relationship.

Evidence to better understand the link between radiation exposure and birth defects has been evolving for decades. The biomedical basis for irradiated organisms causing defects in the fetus dates back to the experiments on fruit flies in the late 1920s [1] [61] [62]. Genetic changes to wild and domestic animals, birds, fish, rodents, mushrooms, insects, spiders, and bacteria after the 1986 Chernobyl meltdown corroborate these earliest discoveries [63] [64]. A lengthy number of reports cited earlier have identified unusually elevated birth defect rates among irradiated human populations.

Documentation of elevated congenital anomaly levels include those exposed to relatively high doses of radiation, including atomic bomb survivors at Hiroshima and Nagasaki, those irradiated by atmospheric nuclear weapons tests in the Marshall Islands, and those living near the Chernobyl reactor that underwent a total meltdown. The research community awaits analyses of congenital anomaly patterns among those exposed in utero to radiation from the Fukushima meltdown. Efforts to establish a consistent association between relatively low dose exposures and congenital anomaly risk are still evolving. The research establishing a risk of cancer death by age 10 after pelvic X-rays during pregnancy represents one form of a fetal insult resulting in subsequent manifestation of disease [65]-[67].

Birth defects result from damage to genes prior to fertilization or damage to the growing cells and tissues in the womb. Fetal insults that can result in defects in the unborn are associated with a number of chemicals, not just radiation. For example, multiple brain defects, as well as eye, facial, heart, genital and limb abnormalities resulted from exposure to the common pesticide chlorpyrifos [68]. Moreover, synergistic effects after exposure to multiple toxins occur. Biologist Rachel Carson's seminal work Silent Spring, which chiefly addressed effects of pesticides, also noted this synergy, specifically mentioning radiation: "In this now universal contamination of the environment, chemicals are the sinister and little recognized partners of radiation in changing the very nature of the world-the very nature of life" [69].

Continued analyses of congenital defects for those exposed to Fukushima fallout are critical. Such defects can include infant and perinatal deaths, stillbirths, low weight births, prematurity, cancer in very young children, and other anomalies. Understanding the short-term consequences to the very young can establish a basis for studies of longer-term effects on persons of all ages, which may only manifest after a latency of up to several decades.

The study of birth abnormalities should emphasize cause as much as detection and therapy, with the eventual goal of prevention. Each affected child causes not just physical and behavioral ramifications to the child, but huge economic and social burdens to the family and society, which may be responsible for the affected person's well-being for decades. A large-scale nuclear meltdown such as the Fukushima disaster presents one such opportunity to better understand cause and means of prevention. Building on the considerable epidemiological evidence of a radiation-congenital anomaly link, plus the knowledge of biochemical actions by radiation that lead to in utero anomalies, a much stronger effort is called for to better quantify the relative doses and the corresponding risk involved in radiation-induced birth defects.

\section{References}

[1] Muller, H.J. (1928) The Effects of X-Radiation on Genes and Chromosomes. Science, 67, 82.

[2] Michel, C. and Fritz-Niggli, H. (1977) Radiation Damage in Mouse Embryos Exposed to 1 Rad X-Rays or Negative Pions. Fortschr Roentgenstr, 127, 276-280. http://dx.doi.org/10.1055/s-0029-1230701

[3] Rugh, R. and Grupp, E. (1959) X-Irradiation Exencephaly. Radiation Therapy, Nuclear Medicine, 81, 1026-1052. 
[4] United Nations Scientific Committee on the Effects of Atomic Radiation (UNSCEAR). Genetic and Somatic Effects of Ionizing Radiation. Report to the General Assembly. United Nations, New York, 1986.

[5] Goldberg M.S., Mayo, N.E., Levy, A.R., et al. (1998) Adverse Reproductive Outcomes among Women Exposed to Low Levels of Ionizing Radiation from Diagnostic Radiography for Adolescent Idiopathic Scoliosis. Epidemiology, 2, 271-278. http://dx.doi.org/10.1097/00001648-199805000-00010

[6] Kochupillai, N., Verma, I.C., Grewal, M.S., et al. (1976) Down’s Syndrome and Related Abnormalities in an Area of High Background Radiation in Coastal Kerala. Nature, 262, 60-61. http://dx.doi.org/10.1038/262060a0

[7] Padmanabhan, V.T., Sugunan, A.P., Brahmaputhran, C.K., et al. (1994) Heritable Anomalies among the Inhabitants of Regions of Normal and High Background Radiation in Kerala: Results of a Cohort Study, 1988-1994. International Journal of Health Services, 34, 483-515. http://dx.doi.org/10.2190/3XYE-QJPU-01BF-8YKE

[8] Yamazaki, N.J. and Schull, W.J. (1990) Perinatal Loss and Neurological Abnormalities among Children of the Atomic Bomb. Journal of the American Medical Association, 264, 605-609. http://dx.doi.org/10.1001/jama.1990.03450050063029

[9] Sawada, S. (2007) Cover-Up of the Effects of Internal Exposure by Residual Radiation from the Atomic Bombing of Hiroshima and Nagasaki. Medicine, Conflict and Survival, 23, 58-74. http://dx.doi.org/10.1080/13623690601084617

[10] Schull, W.J., Otake, M. and Neel, J.V. (1981) Genetic Effects of the Atomic Bombs: A Reappraisal. Science, 213, 1220-1227. http://dx.doi.org/10.1126/science.7268429

[11] Bound, J.P., Francis, B.J. and Harvey, P.W. (1995) Down's Syndrome: Prevalence and Ionizing Radiation in an Area of Northwest England, 1957-91. Journal of Epidemiology and Community Health, 49, 164-170. http://dx.doi.org/10.1136/jech.49.2.164

[12] Sever, L.E., Hessol, N.A., Gilbert, E.S. and McIntyre, J.M. (1988) The Prevalence at Birth of Congenital Malformations in Communities Near the Hanford Site. American Journal of Epidemiology, 127, 243-254.

[13] Lyaginskaya, A.M., Tukov, A.R., Osypov, V.A., et al. (2007) Genetic Effects on the Liquidators. Radiation Biology and Radioactivity, 47, 188-195. In: Yablokov, A.V., Nesternenko, V.B. and Nesterenko, A.V., Eds., Chernobyl: Consequences of the Catastrophe for People and the Environment, New York Academy of Sciences, New York.

[14] Lasjuk, G.I., Nykolaev, D.L. and Khmel, R.D. (1996) Absolute Number and Frequency of Congenital Malformations, Strict Accounting in Some Belarus Regions. Biomedical Aspects of the Chernobyl Accident, 1, 15-17.

[15] Lazjuk, G.I., Nikolaev, D.L. and Novikova, I.V. (1997) Changes in Registered Congenital Anomalies in the Republic of Belarus after the Chernobyl Accident. Stem Cells, 15, 255-260. http://dx.doi.org/10.1002/stem.5530150734

[16] Feshchenko, S.P., Schroeder, H.C., Miller, W.E.G. and Lazjuk, G.I. (2002) Congenital Malformations among Newborns and Developmental Abnormalities among Human Embryos in Belarus after Chernobyl Accident. Cellular and Molecular Biology, 48, 423-426.

[17] Bogdanovich, I.P. (1997) Comparative Analysis of the Death Rate of Children, Aged 0 - 5, in 1994 in Radiocontaminated and Conventionally Clean Areas of Belarus. Medico-Biological Effects and the Ways of Overcoming the Chernobyl Accident Consequence. Collected Book of Scientific Papers Dedicated to the 10th Anniversary of the Chernobyl accident, Ministry of Emergency and Chernobyl Problems of Belarus and Academy of Sciences of Belarus, MinskVitabsk.

[18] Savchenko, V.K. (1995) The Ecology of the Chernobyl Catastrophe. Scientific Outlines of an International Programme of Collaborative Research: Man and the Biosphere series. UNESCO, Paris.

[19] Petrova, A., Gnedko, T., Maistrova, I. and Zafranskaya, M. and Dainiak, N. (1997) Morbidity in a Large Cohort Study of Children Born to Mothers Exposed to Radiation from Chernobyl. Stem Cells, 15, 141-150.

[20] Kulakov, V.I., Sokur, T.N., Volobuev, A.I., et al. (1993) Female Reproductive Function in Areas Affected by Radiation after the Chernobyl Power Station Accident. Environmental Health Perspectives, 101, 117-123.

[21] Shidlovskii, P.R. (1992) General Morbidity of the Population in Districts of the Brest Region. Zhravoohranenie Belorussii (Minsk), 1, 8-11. (In Russian)

[22] Shevchuk, V.F. and Gurachevsky, V.L., Eds. (2006) Twenty Years after the Chernobyl Catastrophe: Consequences for Belarus Republic and Its Surrounding Area. National Belarussian Report, Minsk, Belarus.

[23] Godlevsky, I. and Nasvit, O. (1998) Dynamics of Health Status in Residents of Lugyny District after the Accident of the ChNPR. In: Imanaka, T., et al., Eds., Research Activities about the Radiological Consequences of the Chernobyl NPS Accident and Social Activities to Assist the Sufferers by the Accident, Research Reactor Institute, Kyoto University, Kyoto, KURRI-KR-21.

[24] Stepanova, E.I., Vdovenko, V.Iu. and Misharina, Zh.A. (2007) Postnatal Effects in Children Irradiated during the IntraUterine Development, as a Result of Failure at the Chernobyl NPP. Radiatsionnaia Biologiia, Radioecologiia, 47, 523-529. (In Russian) 
[25] Moumjiev, N., Nedkova, V., Christova, V., et al. (1994) Influence of the Chernobyl Reactor Accident on the Child Health in the Region of Pleven, Bulgaria. Paper presented at 20th International Congress on Pediatrics, 6-10 September 1992. Cited by: Akar, N., Further Notes on Neural Tube Defects and Chernobyl. Paediatric and Perinatal Epidemiology, 8, 456-457.

[26] Kruslin, B., Jukic, S., Kos, M., Simić, G. and Cviko, A. (1998) Congenital Anomalies of the Central Nervous System at Autopsy in Croatia in the Period before and after Chernobyl. Acta Medica Croatica, 52, 103-107.

[27] Korblein, A. (2004) Fehlbildungen in Bayern nach Tschernobyl. Strallentelex, 416-417, 4-6.

[28] Scherb, H. and Weigelt, E. (2003) Congenital Malformations and Stillbirth in Germany and Europe before and after the Chernobyl Nuclear Power Plant Accident. Environmental Science and Pollution Research, 10, 117-125.

[29] (1987) Government of Berlin West, Section of Health and Social Affairs. Annual Health Report.

[30] Lotz, B., Haerting, J. and Schulze, E. (1996) Veranderungen im Fetalen und Kindlichen Sektionsgut im Raum Jena nach dem Reaktorrunfall von Tschernobyl. Oral Presentation at the International Conference of the Society for Medical Documentation, Statistics, and Epidemiology, unpublished manuscript available on request, Bonn, Germany.

[31] Lazjuk, G.I., Zastsepin, I.O., Verger, P., Gagniere, V., Robert, E., Kravchuk, Zh.P. and Khmel, R.D. (2002) Down Syndrome and Ionizing Radiation: Causal Effect or Coincidence? Radiatsionnaia Biologiia, Radioecologiia, 4, 678683. (In Russian)

[32] Zatsepin, I.O., Verger, P., Gagniere, B. and Khmel, R.D. (2004) Cluster of Down’s Syndrome Cases Registered in January 1987 in Republic of Belarus as a Possible Effect of the Chernobyl Accident. International Journal of Radiation Medicine, 6, 57-71.

[33] Ramsay, C.N., Ellis, P.M. and Zealley, H. (1991) Down’s Syndrome in the Lothian Region of Scotland-1978 to 1989. Biomedicine \& Pharmacotherapy, 45, 267-272. http://dx.doi.org/10.1016/0753-3322(91)90028-R

[34] Sperling, K., Pelz, J., Wegner, R.-D., Schulzke, I. and Struck, E. (1991) Frequency of Trisomy 21 in Germany before and after the Chernobyl Accident. Biomedicine \& Pharmacotherapy, 5, 255-262. http://dx.doi.org/10.1016/0753-3322(91)90026-P

[35] Sperling, K., Pelz, J., Wegner, R.-D., Dorries, A., Gruters, A. and Mikkelsen, M. (1994) Significant Increase in Trisomy 21 in Berlin Nine Months after the Chernobyl Reactor Accident: Temporal Correlation or Causal Relation? British Medical Journal, 309, 158-162. http://dx.doi.org/10.1136/bmj.309.6948.158

[36] Sperling, K., Neitzel, H. and Scherb, H. (2012) Evidence for an Increase in Trisomy 21 (Down Syndrome) in Europe after the Chernobyl Reactor Accident. Genetic Epidemiology, 36, 48-55. http://dx.doi.org/10.1002/gepi.20662

[37] Burkart, W., Grosche, B. and Schwetzan, A. (1997) Down Syndrome Clusters in Germany after the Chernobyl Accident. Radiation Research, 147, 321-328. http://dx.doi.org/10.2307/3579339

[38] Verger, P. (1997) Down Syndrome and Ionizing Radiation. Health Physics, 73, 882-893. http://dx.doi.org/10.1097/00004032-199712000-00001

[39] Ericson, A. and Kallen, B. (1994) Pregnancy Outcome in Sweden after Chernobyl. Environmental Research, 67, 149159. http://dx.doi.org/10.1006/enrs.1994.1070

[40] Akar, N., Cavdar, A.O. and Areasoy, A. (1988) High Incidence of Neural Tube Defects in Bursa, Turkey. Paediatric and Perinatal Epidemiology, 2, 89-92. http://dx.doi.org/10.1111/j.1365-3016.1988.tb00181.x

[41] Akar, N., Ata, Y., Aytekin, A.F. (1989) Neural Tube Defects and Chernobyl? Paediatric and Perinatal Epidemiology, 3, 102-103.

[42] Caglayan, S., Kayhan, B., Mentesoglu, S., et al. (1990) Changing Incidence of Neural Tube Defects in Aegean Turkey. Paediatric and Perinatal Epidemiology, 4, 264-268.

[43] Guvene, H., Uslu, M.A., Ozekici, U., Kocabay, K. and Bektaş, S. (1993) Changing Trend of Neural Tube Defects in Eastern Turkey. Journal of Epidemiology \& Community Health, 47, 40-41. http://dx.doi.org/10.1136/jech.47.1.40

[44] Zieglowski, V. and Hemprich, A. (1999) Facial Cleft Birth Rate in Former East Germany before and after the Reactor Accident in Chernobyl. Mund-, Kiefer- und Gesichtschirurgie, 3, 195-199. (In German) http://dx.doi.org/10.1007/s100060050129

[45] Scherb, H. and Weigelt, E. (2004) Cleft Lip and Cleft Palate Birth Rate in Bavaria before and after the Chernobyl Nuclear Power Plant Accident. Mund-, Kiefer- und Gesichtschirurgie, 8, 106-110. (In German)

[46] Mocan, H., Bozkaya, H., Mocan, Z.M. and Furtun, E.M. (1990) Changing Incidence of Anencephaly in the Eastern Black Sea Region of Turkey and Chernobyl. Paediatric and Perinatal Epidemiology, 4, 264-268. http://dx.doi.org/10.1111/j.1365-3016.1990.tb00649.x

[47] Dolk, H. and Nichols, R. (1999) Evaluation of the Impact of Chernobyl on the Prevalence of Congenital Anomalies in 17 Regions of Europe. EUROCAT Working Group. International Journal of Epidemiology, 28, 941-948. http://dx.doi.org/10.1093/ije/28.5.941 
[48] Busby, C., Lengfelder, E., Pflugbeil, S. and Schmitz-Feuerhake, I. (2009) The Evidence of Radiation Effects in Embryos and Fetuses Exposed to Chernobyl Fallout and the Question of Dose Response. Medicine, Conflict, and Survival, 25, 20-40. http://dx.doi.org/10.1080/13623690802568954

[49] Hoffmann, W. (2001) Fallout from Chernobyl Nuclear Disaster and Congenital Malformations in Europe. Archives of Environmental Health, 56, 478-484. http://dx.doi.org/10.1080/00039890109602895

[50] Akimoto, S. (2014) Morphological Abnormalities in Cell Forming Aphids in a Radiation-Contaminated Area near Fukushima Daiichi: Selective Impact of Fallout? Ecology and Evolution, 4, 355-369. http://dx.doi.org/10.1002/ece3.949

[51] Mangano, J. and Sherman, J. (2013) Elevated Airborne Beta Levels in Pacific/West Coast US States and Trends in Hypothyroidism among Newborns after the Fukushima Nuclear Meltdown. Open Journal of Pediatrics, 3, 1-9.

[52] Mangano, J., Sherman, J. and Busby, C. (2013) Changes in Confirmed Plus Borderline Cases of Congenital Hypothyroidism in California as a Function of Environmental Fallout from the Fukushima Nuclear Meltdown. Open Journal of Pediatrics, 3, 370-376. http://dx.doi.org/10.4236/ojped.2013.34067

[53] U.S. Centers for Disease Control and Prevention. CDC Wonder. http://wonder.cdc.gov/natality.html.

[54] Pampfer, S. and Streffer, C. (1988) Prenatal Death and Malformations after Irradiation of Mouse Zygotes with Neutrons or X-Rays. Teratology, 37, 599-607. http://dx.doi.org/10.1002/tera.1420370609

[55] Jaikrishan, G., Sudheer, K.R., Andrews, V.J., et al. (2013) Study of Stillbirth and Major Congenital Anomaly among Newborns in the High-Level Natural Radiation Areas of Kerala, India. Journal of Community Genetics, 4, 21-31. http://dx.doi.org/10.1007/s12687-012-0113-1

[56] Bastout, S., Jackuet, P., Michaux, A., et al. (2002) Developmental Abnormalities Induced by X-Irradiation in p53 Deficient Mice. In Vivo, 16, 215-221.

[57] Castilla, E.E. and Orioli, I.M. (1985) Epidemiology of Neural Tube Defects in South America. American Journal of Medical Genetics, 22, 695-702. http://dx.doi.org/10.1002/ajmg.1320220406

[58] U.S. Environmental Protection Agency. Office of Radiation Protection. http://oaspub.epa.gov/enviro/erams query.v2.simple

[59] Tiwari, R.C., Clegg, L.X. and Zou, Z.H. (2006) Efficient Interval Estimation for Age-Adjusted Cancer Rates. Statistical Methods in Medical Research, 15, 547-569. http://dx.doi.org/10.1177/0962280206070621

[60] Committee on the Biological Effects of Ionizing Radiation (1990) Health Effects of Exposure to Low Levels of Ionizing Radiation: BEIR V. National Research Council, National Academy Press, Washington DC.

[61] Muller, H.J. (1927) The Problem of Genetic Modification. Zeit ind. Abst. und Vereb, Supp. 1, 234-260.

[62] Muller, H.J. (1927) Artificial Transmutation of the Gene. Science, 66, 84-87. http://dx.doi.org/10.1126/science.66.1699.84

[63] Møeller, A.P. and Mousseau, T.A. (2007) Determinants of Interspecies Variation in Population Declines of Birds after Exposure to Radiation at Chernobyl. Journal of Applied Ecology, 44, 909-919. http://dx.doi.org/10.1111/j.1365-2664.2007.01353.x

[64] Møeller, A.P., Mousseau, T.A., de Lope, F. and Saino, N. (2007) Elevated Frequency of Abnormalities in Barn Swallows from Chernobyl. Biological Letters of the Royal Society, 3, 414-417. http://dx.doi.org/10.1098/rsbl.2007.0136

[65] Stewart, A., Webb, J., Giles, D. and Hewitt, D. (1956) Malignant Disease in Childhood and Diagnostic Irradiation in Utero. The Lancet, 268, 447. http://dx.doi.org/10.1016/S0140-6736(56)91923-7

[66] Stewart, A., Webb, J. and Hewitt, D. (1958) A Survey of Childhood Malignancies. British Medical Journal, 1, 14951508. http://dx.doi.org/10.1136/bmj.1.5086.1495

[67] MacMahon, B. (1962) Prenatal X-Ray Exposure and Childhood Cancer. Journal of the National Cancer Institute, 28, 1173-1192.

[68] Sherman, J.D. (1999) Chlorpyrifos (Dursban) Exposure and Birth Defects: Report of 15 Incidents, Evaluation of 8 Cases, Theory of Action, and Medical and Social Aspects. European Journal of Oncology, 4, 653-659.

[69] Carson, R. (1962) Silent Spring. Crest Books, New York. 


\section{Appendix}

Appendix 1. Sites used to calculate gross beta in air, 2010 and 2011.

\begin{tabular}{|c|c|}
\hline$\underline{\text { PACIFIC/WEST COAST }}$ & OTHER U.S. \\
\hline *Anchorage AK & Montgomery AL \\
\hline Anaheim CA & Little Rock AR \\
\hline *Bakersfield CA & Tucson AZ \\
\hline Eureka CA & Denver CO \\
\hline Fresno CA & Washington DC \\
\hline Los Angeles CA & Des Moines IA \\
\hline Richmond CA & Indianapolis IN \\
\hline *Riverside CA & Kansas City KS \\
\hline *Sacramento CA & Topeka KS \\
\hline *San Bernardino CA & Lexington $\mathrm{KY}$ \\
\hline San Diego CA & Baton Rouge LA \\
\hline San Francisco CA & Worcester MA \\
\hline San Jose CA & Bay City MI \\
\hline *Hilo HI & Detroit MI \\
\hline *Honolulu HI & Jefferson City MO \\
\hline "Portland OR & Springfield MO \\
\hline *Olympia WA & Jackson MS \\
\hline \multirow[t]{13}{*}{ "Spokane WA } & Charlotte NC \\
\hline & Edison NJ \\
\hline & Trenton NJ \\
\hline & Albany NY \\
\hline & Cleveland $\mathrm{OH}$ \\
\hline & Cincinnati $\mathrm{OH}$ \\
\hline & Pierre SD \\
\hline & Oak Ridge TN \\
\hline & Dallas TX \\
\hline & San Angelo TX \\
\hline & Salt Lake City UT \\
\hline & Lynchburg VA \\
\hline & Richmond VA \\
\hline
\end{tabular}

*Sites with the most frequent (at least 24) measurements for March 15-April 30 in 2010 and 2011, and at least 100 for all other dates in the period January 1-October 4 in 2010 and 2011. 